The Unity of Intellect and Will: Vygotsky and Spinoza

\begin{abstract}
Jerome Bruner points out in his prologue to the first volume of the English translation of The Collected Works that Vygotsky flirts with the idea that language creates free will. This paper attempts to consider the influence of the Dutch seventeenth-century philosopher Spinoza on Vygotsky. An account of Spinoza's anti-Cartesian conception of will is given, to which Vygotsky recognises his indebtedness. We will consider elements of Spinoza's philosophy that were important to Vygotsky's theory of the development of intellect, and claim that an appreciation of the philosophy informing Vygotsky's theory of the development of intellect is necessary if the full implications of his project are to be grasped.
\end{abstract}




\section{The Unity of Intellect and Will: Vygotsky and Spinoza}

Jerome Bruner opens his introduction to the 1962 edition of Thought and Language with the comment that the principal theme of the phase of Vygotsky's work that dealt with the relation between thought and language was 'a highly original and thoughtful theory of intellectual development'. By the time of writing his prologue to the English edition of The Collected Works in 1987 he remarks that 'Vygotsky's depth was far greater than [the early publication in English] suggested.' As many commentators since the 1960s had made evident Thought and Language was only 'the tip of the iceberg'. Bruner notes that far more is implied in Vygotsky's work than might appear evident on an initial reading. One of these implications relates to the idea of freedom, that is freedom as selfdetermination rather than simply absence of constraint. Bruner goes as far as to claim that 'in the end, Vygotsky flirts with the idea that the use of language creates consciousness and even free will' (Bruner, 1987).

This hint at a relationship between free will and the development of consciousness via the mediation of language is full of promise. But in what way might such promise be fulfilled? Many commentators have noted the limited development of Vygotsky's ideas and the restrictions placed upon him by his short working life (Van der Veer \& Valsiner, 
1993). The extent, however, to which his ideas have continued to be appropriated in such various fields as work on the nature of mind, schooling and organisational learning, stands testimony to his originality.

This article considers the relationship between free will and the development of consciousness in the light of the philosophical background to Vygotsky's work. The research involved in the paper stems from a more general argument that the philosophy informing Vygotsky's work has not been fully appreciated in contemporary interpretations and that this shortcoming has affected the way in which his work has been interpreted in relation to practical educational questions. As Bruner notes, Vygotsky's theory of the development of intellect is not only a theory of education but also a step into the terrain of fundamental questions about the nature of what it is to be human. As such it engages with philosophical questions in more than a merely illustrative way.

Vygotsky made a bold claim in relation to free will: the work he was undertaking with colleagues in psychology examined the nature of mind as embodied in activity that sustains and constitutes it. Through this undertaking he was to grapple with the issue of freedom in a way that began to merge psychological research with philosophy, in particular the philosophy of Spinoza. Indeed his psychological studies were beginning to give real insight into the most fundamental of questions: 
The philosophical perspective opens before us at this point of our study. For the first time in the process of psychological studies we can resolve essentially purely philosophical problems by means of a psychological experiment and demonstrate empirically the origin of the freedom of the will... We cannot help but note that we have come to the same understanding of freedom and control as Spinoza developed in his 'Ethics' (Vygotsky, 1997).

Vygotsky understood that what he was working on coincided with Spinoza's understanding of freedom in the Ethics. He criticised Descartes for his explanatory inadequacy in failing to 'make a clear distinction between passions of the soul and passions of a soulless machine' (Vygotsky, 1999). He was also acutely aware of the difficulty of theorising will and distinguishing it from the sort of mechanical explanation that would only be reasonable when discussing machines:

In the final analysis, the question is: does what is higher in man, his free and rational will and his control over his passions, allow a natural explanation that does not reduce the higher to the lower, the rational to the automatic, the free to the mechanical, but preserves all the meaning of this higher aspect of our mental life in its fullness, or to explain 
the higher, do we inevitably have to resort to rejecting the laws of nature, to introducing a theological and spiritualistic principle of absolute freewill not subject to natural necessity? (Vygotsky, 1999)

What was Vygotsky hinting at when he said that for the first time psychological studies were at a point of getting to grips with the problem of freedom in a quite different and empirical way?

Freedom has been a perennial question in philosophy. In modern times freedom is more often than not presented as freedom from constraint. When considering the concept of freedom it is necessary to be aware that it has different meanings for different traditions. The sense in which we commonly think of ourselves as free actors owes much to Descartes' modernist separation of mind and world. But Vygotsky was referring to a very different notion of freedom from the popular one exemplified by the idea of free choice and absence from constraint. Thus to understand the sense of free will that informs Vygotsky's work it is necessary to get to grips with the conception of freedom which derives from the work of Spinoza (later taken up and developed by Hegel). This is not easy, since it seems counter-intuitive and goes against our sense of our activities resulting directly from the exertion of our will. To make matters even more complicated, we inhabit a world in which social 
institutions and structures are premised implicitly on a Cartesian notion of will (Ilyenkov, 1977; Gergen, 1999). That is, our mode of existence in modern times has a particular conception of will built into it. According to this conception we inhabit a social milieu of institutions and practices in which our activity appears as the result of the independent exertion of will. In our common sense conception, will presents itself to us as a capacity, a power vested within ourselves. This power (located in the soul according to Descartes) is set apart from the world of matter upon which we act, as an independent force. Coupled to this everyday common-sense conception of freedom is the idea that free will is the unencumbered pursuit of the objects of desire - 'free to consume what I like'. Presupposed here is that what-I-am is what-I-desire (my identity is an outcome of my consumption patterns). There is little thought that desires may not be genuinely my own, i.e. not my own in the sense that they determine me externally.

Although the question of freedom appears esoteric in relation to the concerns of educationalists, it clearly informs educational practices. It can be understood as forming part of the 'folk psychologies' (Bruner, 1996) underlying pedagogic practices. For instance, some practices of 'child centred education' emphasising the 'rights' of children to follow their own interests/desires/wants, are premised upon the Cartesian conception 
of will. The possibility that will may be thought of in a different way (as inextricably linked to intellect) presents an interesting challenge.

The Hegel scholar, Robert Pippin, took up this question of 'desires being my own' in an address to new undergraduates starting their degrees at Chicago: he called upon his audience to consider on what basis they might be sitting in front of him at that moment. He asked them to dwell on why they had come to study. A free choice - he reflected - or a more guarded decision following parental pressure? He proceeded to ask them to consider what being free might mean in such an educational context. He suggested that unless they have a better idea of why they might be listening to him then they had not come 'freely'. More provocatively, he suggested that the reason to come to Princeton might be to find out their reason to come. His point was that his audience may not have made a free decision in this sense but experience instead a degree of alienation where the decision to come is 'part of your life, [yet] while it was in fact produced by you, does not truly reflect the "you" that you understand yourself to be and identify with, and so this decision cannot in the deepest sense be yours' (Pippin, 2000). In alerting new students to the question of what it means to become educated, Pippin is communicating a counterintuitive notion of freedom steeped in the tradition of philosophy from which Vygotsky drew. 
To be educated is also a process of which becoming free is intrinsically a part, for to be educated is not to 'know' a range of positions and perspectives but to understand the reasons for holding particular beliefs and rejecting others. Pippin continues:

[I] imagine all of us playing a version of the game where we try to name an idea crucial to our understanding of ourselves and of the modern world, and which has played a critical role in some of our decisions, some of the policies we have formulated, and many of the judgments and even condemnations we have formulated about others, but which we have no clue how to define and, no matter how much we have relied on it, no clue at all how to defend the idea from objections. Examples come easily to mind to all of us. What, after all, is a "right"? (Pippin, R. 2000) In such a scenario we would not be familiar with the reasons for our actions and judgments and therefore we would be subject to them rather than in control of them: '[A] better form of self-understanding might make it possible to say that you led a life more "your own."' (Pippin, R. 2000.) It is in this sense that education is a freedom-enhancing process: to put the point simplistically in Spinozist terms, to know the reasons why I act is to be a cause of myself (causa sui) rather than to be the subject of extraneous determinations. The responsibility of a scholar to interrogate 
and attempt to understand the reasons for a belief or perspective is developmental to both mind and free will:

One way of understanding the possibility of a free life "your own life" - is to consider which of your past decisions you could truly be said to be able to "stand behind," where that means being able to defend or justify them when challenged, or even which you could claim to understand. "Having reasons" in this sense for what you did, having something to say about "why," is a general condition for some event being considered an action of yours at all, and not having any reasons means it is very hard to understand any link between you and what conduct you engage in. (Pippin, 2000)

It is undoubtedly Pippin's Hegel scholarship that informed his encouragement of new students to approach their higher education in this way. Vygotsky was similarly informed by the tradition of Spinoza and Hegel, in which the development of will and the intellect are intricately interconnected. For Vygotsky, intellect is a key aspect of will yet at the same time, contrary to the idea of unencumbered choice, it is by its nature restrained. In Vygotskian literature, the development of intellect is understood as embedded - thus the coexistence of freedom and restraint is not the problem that it is in some contemporary versions of freedom. One 
of Vygotsky's most significant contributions was to examine mind as embedded in material activity rather than existing independently of the world that it would come to know. His interest in how 'mindedness' is formed and sustained by mediation with artefacts in a social domain has opened a major area of educational research (Cole 1996).

Spinoza's philosophy provided Vygotsky with a different understanding of freedom from the contemporary popular version of unrestrained free choice. Spinoza's conception of freedom is so different that some commentators have viewed him as a mechanical determinist without any notion of freedom at all (Jay, 1984, p. 29)

It is necessary to understand a number of elements of Spinoza's philosophy to comprehend that he does indeed have a concept of freedom and to see how this differs from the common-sense notion of free will. For Spinoza it is in self-determination that human beings exhibit freedom. A free agent is not one whose actions are undetermined, but one whose actions are self-determined and self-determination arises only when we are not controlled by our passions. A passion here is not the same as an affective impulse; rather it is what Spinoza called an affect produced by external causes rather than by our own power. We are not controlled by passions when we understand the reasons for our actions is based on 
adequate ideas. To be guided by adequate rather than inadequate knowledge is to be free from external determination.

Free will for Spinoza is not separated from his idea of truth (adequate ideas). An appreciation of this lack of separation is necessary to grasp Vygotsky's epistemological stance. For Spinoza, truth is necessary for freedom as his conception of freedom is integral to his epistemology. Truth is the correlate of adequate ideas while falsity is a characteristic of incomplete ideas or privation of knowledge. Free will only arises when humans are active rather than passive. In turn, actions which are active in Spinoza's terms (i.e. self-determined) are only possible when such actions coincide with adequate rather than inadequate ideas. Vygotsky notes approvingly inextricable connection which Spinoza drew from affects, thought and quality of action: 'Spinoza...defined affect as that which increases or decreases our body's ability to act, and that which forces thought to move in a particular direction' (Vygotsky, 1993, p.234). This is a deeper, more ontologically embedded notion than the simplistic idea that the possibility of free-action depends upon sufficient knowledge. That is to say adequate ideas, understanding and self-determination are party and parcel of each other.

Spinoza took issue with the Cartesian conception of will grounded in a separation of the material world from a wilful mind capable of free 
action in relation to it. He ridiculed the common-sense notion of free will: '...so firmly are they persuaded that the body is moved by mere command of the mind, or is kept at rest, and that it performs many things which merely depend on will or ingenuity of the mind' (Spinoza, 1993). He also denies it: 'The body cannot determine the mind to think, nor the mind the body to motion, nor to rest, nor to any other state (if there be any other)' (Spinoza, 1993). The belief that we have the power to act in the world free from any material restraint of our circumstance was caricatured by Spinoza as a metaphysical faith in will. Vygotsky cites Spinoza on this very point of contention:

Spinoza most acutely contrasts his thought with Descartes. Spinoza claims that Descartes... significantly promotes the false opinion that affects depend absolutely on our will and that we can control them infinitely. Spinoza says that he cannot 'be surprised enough that a philosopher, having strictly held to reaching conclusions only on the basis of sources that are certain of themselves [Descartes said he wanted to build his philosophy only on the firm foundations of certain ideas] and claiming only what he recognises clearly and definitely, and so frequently reproving the scholastics for thinking to explain dark things by hidden 
properties, how this philosopher accepts a hypothesis that is

darker than any dark property.' (Vygotsky, 1999)

In contrast to Descartes, who assumed free will without accounting for the source of its power, Spinoza provided the argument that free will arises in the development of intellect, and Vygotsky benefits from this insight. Whereas for Descartes 'the will' and 'the understanding' (intellect) are distinct, for Spinoza they are the same (Kashap. 1987). This is also the case for Vygotsky for whom there is no stark separation between will and intellect; Vygotsky's investigation of the sociogenesis of mind requires that mind is understood in terms of its activity. Spinoza's point that the mind cannot simply will the body into action and that an explanation of will in these terms is no explanation, was adopted by Vygotsky, who appreciated that the mind moves and is moved in activity. Self-determination is not possible through a pure act of will, but arises in (indirect) mediation - the mind is steered towards its intention. Vygotsky cites the case of Buridan's ass where the animal is unable to choose between the stimuli of two equal bales of hay and thus starves. $\mathrm{He}$ uses the tale to distinguish the possibility of freedom in human activity through the use of mediating artifacts. In the simple case of an inability to decide, a human may toss a coin. No matter that the point is trivial, the human has an additional means of interaction with external determination; the ass lacks such a means (Vygotsky, 1997). For 
Vygotsky, following Spinoza, the basis of freedom is man's ability to separate himself from his passions, from the contingencies of nature, and to make for himself a space within which he can determine his actions. Such actions are determined not by external and independent causes but by those that lie within ones sphere of efficacy.

It is possible to discern this concept of freedom in Vygotsky, as for instance when he discusses the sense in which consciousness is just assumed by Piaget (Vygotsky, 1987). For Piaget, consciousness occurs in the child once the bankruptcy of his own thinking is evident, whereas for Vygotsky consciousness arises through a subject's changing location to external forms of determination. Vygotsky looks to the unfolding mediation of consciousness rather than its arbitrary positing in terms of the evaporation of egocentric speech as egocentric thought atrophies. Vygotsky takes issue with the way that 'Piaget represents the child's mental development as a process where the characteristics of the child's thought gradually die out' (Vygotsky, 1987, p.175). He finds the genesis of consciousness in the development of scientific concepts and contrasts his research with Piaget's arguing that Piaget only sees the difference/opposition between the child's spontaneous and nonspontaneous concepts (scientific concepts) but not their identity (Vygotsky, 1987). Vygotsky criticises Piaget's failure to understand that a child's lack of conscious awareness was affected by his position in 
relation to what he was asked to understand, rather than to a conflict between his own childish concepts and those which gave him access to reality. Human behaviour according to Vygotsky is neither controlled nor directed by immediate means based on pure acts of will, but is moved indirectly through the use of signs and tools. The modification of the world by human activity creates an artificiality (or 'artefactuality') of conditions. Within such artificial and man-made conditions volition can be directed/mediated (caused), but in these circumstances the cause of an action arises through man's own creations/artefacts and not merely in response to external determinations. The 'ability to conform to the dictates of no particular situation, but to any' (Bakhurst, 1991, p.251) provides for human beings the possibility of a universality not available to animals which do no more than respond directly to environmental determinations i.e. without conscious mediation or reflection. What is significant in the analysis of these issues in Vygotsky's work, is the symbiotic relation between the development of consciousness and scientific concepts, the ability to operate actively on matter rather than being its passive subject.

Vygotsky followed Spinoza, in asking crucial questions: how to free ourselves from our concrete circumstances, from our passions; how to be free, not determined by external causes but to be a cause of ourselves (causa sui). A key point of Spinoza's Ethics was the rejection of a 
'disembodied' will. According to Spinoza we are not able to control ourselves directly through a will not tied to matter:

[As Spinoza correctly believed,] Thought prior to and outside of its spatial [external] expression in appropriate material forms simply does not exist' (Ilyenkov, E. cited by Bakhurst, D. 1991).

We can only achieve freedom by altering our position in relation to external determinations or as Vygotsky put it, by creating extrinsic stimuli.

Spinoza explains the relationship of will and conscious awareness as characteristic of concepts located in relation to one another, i.e. systemically. The more our actions are formed by adequate ideas (i.e. ideas where the genetic connections are understood explicitly) the more we are determinate of our own actions and, as such, active. The more we act according to inadequate ideas (ones whose relations are unexpressed) we are said to be passive and as such our actions are not free:

The physical and mental behaviour of a human being... may be active or passive to various degrees. The more it stems distinctively or creatively from its own conatus, the more active it is; the more it is merely acted on by external things, the more passive it is. (Sprigge, 1995) 
Thus for Spinoza free action is not a matter of choice or volition but of the mind's activity as opposed to passivity. Activity for Spinoza concerned the quality of action rather than the mere fact of acting: the mind is active when its ideas are adequate and passive when its ideas are inadequate. For Spinoza, we are said to act when we are the adequate cause of our actions; that is, when the ideas on which our actions are based are adequate ideas. This is a totally different sense of action from the common one that makes no such profound distinction. So many of the actions that we feel ourselves to be engaged would, according to Spinoza's line of argument, be understood as vain repetitions. Often such repetitions perpetuate what they are intended to change. This, of course, is a standard psychotherapeutic position, where an action that is claimed by a patient to be effective is revealed to be preserving the situation that the patient wishes to change. For Spinoza such activity, though it comprises concrete actions, is not really activity at all; or it is passivity, to be precise, because it is driven by inadequate ideas.

The argument of this paper has been restricted to the influence of Spinoza on Vygotsky. Vygotsky considered freedom in Spinoza's sense of self-determination as integral to education as a specifically human process of coming to be in the world. The emphasis of this line of enquiry tends to be placed upon the general character of education, rather than upon its specific practices. Since the assessment of specific, practices 
depends on suppositions about the general nature of education, this emphasis is rather a first step than a final statement. The point of this paper à propos Vygotsky's thought is that this first step requires philosophical work.

\section{References}

Bakhurst, D. (1991) Consciousness and Revolution in Soviet Philosophy: From the Bolsheviks to Evald Ilyenkov Cambridge University Press.

Bruner, J. (1987) 'Prologue to the English Edition' in N. Minick, (trans), R.W. Reiber and A.S. Carton (eds) L.S.Vygotsky (1987) The Collected Works of L.S. Vygotsky, Volume 1 Problems of General Psychology Plenum Press, New York and London.

Bruner, J. S. (1996) The Culture of Education Cambridge, MA: Harvard University Press.

Damasio, A. (2003) Looking for Spinoza: Joy, Sorrow and the Feeling Brain William Heinemann: London 
Gergen, K.J. (1999) An Invitation to Social Construction London: Sage Publications.

Hardt, M. (1993) Gilles Deleuze: An Apprenticeship in Philosophy University College London Press.

Ilyenkov, E.V. (1977) 'The Concept of the Ideal' in Philosophy in the USSR: Problems of Dialectical Materialism Moscow: Progress Publishers.

Kashap, S.P. (1987) Spinoza and Moral Freedom State University of New York Press.

Pippin, R. (2000) Liberation and the Liberal Arts annual talk at the University of Chicago, URL: http://www.uchicago.edu/docs/education/aims2000.html [accessed: 1.10.2003].

Spinoza, B. (1993) Ethics and treatise on the correction of the intellect (Boyle, trans.) London Everyman, J.M.Dent. 
Sprigge, T.L.S. (1995) 'Spinoza' in Honderich, T. (ed.) The Oxford Companion to Philosophy Oxford University Press, Oxford, New York.

Van der Veer, R. \& Valsiner, J. (1993) Understanding Vygotsky: A Quest for synthesis Oxford, UK: Blackwell.

Van der Veer, R. \& Valsiner, J. (1994) The Vygotsky Reader Oxford, UK: Blackwell.

Vygotsky, L.S. (1987) The Collected Works of L.S. Vygotsky, Volume 1 Problems of General Psychology, (including the Volume Thinking and Speech) Minick, N. (trans.), Reiber, R.W. \& Carton, A.S. (eds) Plenum Press.

Vygotsky, L. S. (1997) The Collected Works of L.S. Vygotsky, Volume 4, The History and Development of Higher Mental Functions R.W. Reiber (ed) M.J. Hall (trans.) Prologue by J. Glick, New York: Plenum Press.

Vygotsky, L.S. (1999) The Collected Works of L.S. Vygotsky, Volume 6,

Scientific Legacy, Reiber, R.W. (ed) M.J. Hall (trans.) Prologue by D. Robbins, New York: Kluwer Academic/ Plenum Publishers. 